\title{
Foreword and acknowledgements
}

This book is the result of close co-operation between EU antitrust officials and academic economists. As a result, it is neither a comprehensive overview of the economic literature on the telecommunications industry, nor a detailed presentation of antitrust principles and caselaw for that sector. Instead, it aims to address the integration of economics with the factual specificities of the telecommunications industry in order to further enhance the treatment of antitrust cases in the sector.

This aim is reflected in the fact that half of the contributions are from EU officials (mainly from the antitrust unit in charge of the telecommunications industry), while the other half are from academic economists. As a result, the reader will find, in each chapter, both an economist's perspective and the view of a Commission case-handler. The opinions expressed by Commission officials are the personal view of the speakers and do not necessarily reflect the position of the Commission.

We hope that this work will help foster the dialogue between outside academics and insider experts in Europe and contribute to a convergence of legal and economic approaches to EU antitrust policy.

This work documents a conference, 'The economics of antitrust and regulation in the telecommunications sector', held in Brussels on 16 September 2002. That conference was the culmination of a one-year project in which officials from the telecoms unit of the European Commission's DG Competition and a group of high-level European economists worked together on a number of key issues in the telecommunications sector. The topics, namely market definition, collective dominance, access to networks, and allocation of scarce resources, were chosen on the basis of the key problems arising out of the antitrust cases pending at the time.

The aim of the project was to incorporate modern economic theory and tools into day-today antitrust casework. To that aim, a number of meetings took place, which were devoted to discussion of the economic 'toolbox' available on the various issues and of the main characteristics of the relevant cases. These meetings then progressively led to a closer interaction between advisers and case-handlers and for a dialogue more tailored to specific cases.

The last meeting took the form of an open conference in which the experts highlighted the main theoretical and empirical findings relating to the above-mentioned topics, while DG Competition officials presented specific situations where this economic analysis was particularly relevant.

The conference was introduced by Commissioner Monti and structured around five thematic sessions and a closing roundtable, chaired by Philip Lowe, Michael Katz and Jean Tirole. Each session consisted of two presentations, given by an academic expert and a DG Competition official in turn, followed by a discussion with comments and questions from the floor (consisting of some fifty invited competition lawyers, consultants, economists and academics as well as Commission staff). 
Part I begins with the opening remarks by the European Commissioner for Competition, Mario Monti, who presents the main challenges of competition and regulatory policies in the electronic communications sector. The contributions of the experts and the Commission officials are structured in five sections:

\section{The New Regulatory Telecommunications Framework}

Pierre Buigues (Head of Unit, DG Competition, European Commission) presents the approach of the new regulatory framework. Based on competition law, the new framework provides for, inter alia: the convergence of the concept of 'significant market power' (used in the sector-specific legislation) with the (competition-law-based) notion of 'dominance'; the use of competition-law analysis for the definition of markets; and the determination of the list of markets to be regulated (namely those markets where competition-law remedies are considered insufficient).

Martin Cave (Warwick Business School) comments on the economic aspects of the new regulatory framework. He views the new framework as a road towards deregulation and reliance on competition law, and considers its remedies as less intrusive and more effective than those under the previous framework. He points out, however, the complexity of its implementation, due mainly to the multiplication of markets to be analysed, the poor guidance on the choice of remedies, and the complex and potentially divisive institutional interaction.

\section{Market Definition in Telecommunications Markets}

Jordi Gual (IESE Business School) criticizes the Commission for using overly narrow market definitions in its antitrust and regulatory practices, and for failing to take sufficient account of supply-side substitution, complementary products and bundles of goods when determining the scope of a relevant market for antitrust purposes.

Christian Hocepied (European Commission) outlines the market delineation process contained in the new regulatory framework, first by reference to the markets contained in the Recommendation on relevant markets to be regulated, and, second, by reference to the Guidelines on market analysis and the assessment of significant market power in the electronic communications sector.

\section{Economic Analysis of Collective Dominance in Telecoms Markets}

Patrick Rey (University of Toulouse) presents the necessary ingredients (including entry barriers, frequent interaction and low innovation) and important factors (such as the number of firms, symmetries, structural links) for the existence of a collective dominant position in a given market. He compares the concept of collective dominance with the economic concept of tacit collusion, and considers the difficulties that antitrust authorities might encounter in applying this concept.

Lambros Papadias (European Commission) discusses the legal aspects of collective dominance by reference to the existing case-law and the recently adopted Commission Guidelines on market analysis and the assessment of significant market power in the electronic communications sector.

\section{Economic Aspects of Access to Networks}

Marcel Canoy (CPB), Paul de Bijl (TILEC) and Ron Kemp (EIM) describe the problems relating to access to telecommunications bottlenecks, and analyse the various solutions 
available to regulators and competition authorities. They explain the drawbacks and benefits of using static and dynamic pricing strategies to achieve short-term service-based competition and long-term infrastructure-based competition. They also stress the difficulties created by asymmetric information for the implementation of regulatory and competition policy in the case of access problems.

Juan Delgado, Jérôme Fehrenbach and Robert Klotz (European Commission) describe the current situation of local loop unbundling in Europe. They note the poor results achieved after the entry into force of the unbundling Regulation, in part caused by the incumbents' behaviour and the current price structure. Local loop unbundling prices are deemed to be too high, as evidenced by the existence of margin squeezes in certain Member States. Different potential solutions, such as adapting the pricing methodology and the cost methodology, are discussed.

\section{Competition and Allocation of Scarce Resources: the Case of UMTS}

Jörn Kruse's (University of Hamburg) chapter presents the different methodologies that can be used to allocate (intramodal and intermodal) spectrum frequencies and their appropriateness for achieving certain goals (efficiency, social and fiscal objectives, and so on). He supports infrastructure-sharing as a way of reducing costs and speeding up UMTS (universal mobile telecoms system) development, and maintains that detrimental effects on competition will be limited (provided that only the radio access network is shared).

David Gabathuler and Wolf Sauter (European Commission) examine the present and future regulatory framework for frequency allocation and assignment in the EU, in particular in relation to mobile communications, and discuss recent developments towards the introduction of spectrum trading. They also consider the regulatory and competition policy implications of the introduction of $3 \mathrm{G}$ (third generation)/UMTS, with a focus on networksharing and MVNO (mobile virtual network operator) access.

\section{Roundtable on The Economics of Antitrust and Regulation in the Telecoms Sector}

Philip Lowe (Director General, DG Competition, European Commission) introduces the roundtable by reviewing the role of sector-specific regulation and competition law in the context of the new regulatory framework for the telecoms sector.

Michael Katz (Deputy Assistant Attorney-General, US Department of Justice, Antitrust Division) considers the respective roles of antitrust enforcement and regulation. He describes the US situation regarding regulation and the application of antitrust rules, and notes that regulation can go further than competition policy on some issues (for example with regard to essential facilities) and may pursue different goals (such as universal service subsidies). He points out that in some markets competition cannot take place in the absence of regulation, so that antitrust rules will never be a substitute of regulation.

Jean Tirole (IDEI - University of Toulouse) addresses two issues: the role of antitrust in the telecommunications sector and the conceptual challenges faced by competition policy in this sector. He pleads for a balanced approach to regulatory and antitrust enforcement, and argues that there is no need to adapt the antitrust rules to the specific characteristics of the telecommunications sector, but that, instead, a more sophisticated analysis is required. He illustrates his position with three examples: the essential facilities doctrine, the economics of networks (and the problem of access), and the necessity for competitors to co-operate in telecommunications markets. In each case, he compares the problems arising in the telecommunications sector with those of similar nature in other sectors (e.g. patents in research-intensive sectors, compatibility of standards, and so on). 
In Part II, Dessislava Choumelova (ESA) and Juan Delgado (European Commission) present an evaluation of the sector inquiry instrument - a sector-wide investigation into commercial practices relating to an entire sector of the EU economy - which has been used by the Commission in the telecommunications sector for three markets: leased lines, mobile roaming and local loop access. The main results, and a summary of the main findings of the three sector inquiries, are presented.

Finally, Part III reproduces the main regulatory texts of the new regulatory framework and in particular the Directives, the Decision on the European Regulators Group, the guidelines on market analysis and the calculation of significant market power, and the Recommendation on relevant products and service markets susceptible to ex ante regulation.

The academic papers presented in this book and the conference were funded by the European Commission Directorate General for Competition. We are grateful to Juan Delgado, Yves Moulin, Natacha Muller and Valérie Leclercq, whose work was of crucial importance in the co-ordination and production of this book.

The publishers wish to thank the following, who have kindly given permission for the use of copyright material:

Office des Publications Officielles des Communautes Européennes for Main Regulatory Texts. Only European Communities legislation printed in the Official Journal of the European Communities is deemed to be authentic.

Every effort has been made to trace all the copyright holders but if any have been inadvertently overlooked the publishers will be pleased to make the necessary arrangements at the first opportunity.

P.A. Buigues

P. Rey 